\title{
1 Regulation of Organogenesis via PGRs and LEDs Light Technology for Jatropha curcas L. Plants
}

\author{
Ahmed S. Attaya and Eman I. El-Sarag ${ }^{\#}$ \\ Department of Plant Production, Faculty of Environmental Agricultural Sciences, Arish \\ University, North Sinai, Egypt.
}

Received: 29/11/2016

Accepted: 13/2/2017

\begin{abstract}
BECAUSE of the increased interest in the potential of Jatropha as a biofuel plant, more attention is given to methods that allow the mass production of elite material. A simple and efficient protocol has been developed for high frequency regeneration using nodal explants of Madagascar and Ecuador Jatropha curcas lines. The optimum shoot growth with high number and without callus formation was observed using MS medium supplemented with $1.0 \mathrm{mg} / \mathrm{l} \mathrm{BA}$ in both lines within a period of 30-40 days which shows 3.8 and 3.4 shoot buds in Madagascar and Ecuador lines, respectively. Healthy elongated shoots were harvested and cultured on $1 / 2$ strength MS basal salts without vitamins medium containing different concentrations of IBA individual or in combination with IAA or 2,4-D. Moreover, the optimum rooting medium with good root formation (46.6 and $40 \%)$ in both Jatropha lines and $(3.0-2.4)$ roots per shoot containing halfstrength MS supplemented with $0.5 \mathrm{mg} / 1 \mathrm{IBA}$. In the present study, different light sources like cool white fluorescent, warm white fluorescent and different highbrightness LEDs (red - blue - white) were used to monitor the root initiation of in vitro Jatropha shoots. Red LED light provided the most favorable growth conditions inducing a rooting response in $66.6 \%$ of the shoots in Madagascar Jatropha and $56.5 \%$ in Ecuador Jatropha which produced on average 4.2 and 3.5 roots per shoot, respectively in both lines. Thus, white LED light was more effective on root elongation than all studied light treatments that recorded (5.6 and $4.4 \mathrm{~cm}$ ) root length in both lines. Therefore, well developed healthy in vitro rooted plantlets after 6 weeks were successfully acclimatized and the survival rate of in vitro propagated plantlets after transplanting was $40-60 \%$ and they grew as normal plants in the greenhouse.
\end{abstract}

Keywords Jatropha curcas, Organogenesis, Plant growth regulators (PGRs), in vitro Rooting, Light-Emitting-Diodes (LEDs)

\section{INTRODUCTION}

Jatropha curcas is a species of flowering plant in the spurge family (Euphorbiaceae). Jatropha genus is large comprising more than 170 species succulent plants. Most of shrubs and trees are ornamental except $J$. curcas and $J$. glandulifera that are oil-yielding species (Swarup, 2004). It has rapid growth, easy propagation, low seeds cost, high oil content (up 60\%) which can be transformed into fuel through esterification ( $\mathrm{Li}$ et al., 2007). Easy, wide adaptation and root architecture involves a pen root that grows to great depths highly suitable for fixing the soil and the prevention of erosion so it can be used for reclamation of waste lands (Achten et al., 2007). The optimum plant size makes the seed collection convenient (Jones \& Miller, 1991; Francis et al., 2005 and Kumar \& Sharma, 2008).

Energy experts claim that Jatropha oil is an environmentally safe, cost-effective and a promising substitute for diesel, kerosene and other fuels (Abdulla et al., 2011). Jatropha oil is high in cetane value and can be used directly in diesel engines added to diesel fuel as an extender or transesterized to a biodiesel fuel but also it is not edible due to the presence of several toxic substances such as "curcasine" or curcin, phorbol esters, saponins, protease inhibitors and phytates (Menezes et al., 2006 and Datta et al., 2007). Conventionally, propagation through seeds is a widely used but it is not favorable because of loss of genotype homogeneity due to out-crossing and it is beset with problems of poor seed viability, low germination, scanty and delayed rooting of seedlings (Daud et al., 2013). On the other hand, mass propagation through stem cuttings are seasonal, seed yield are low, were reported to generate plants with a lower longevity, a lower drought and disease resistance therefore the established plants are not deep rooted, hence are easily uprooted as they do not form a taproot

\footnotetext{
\#Corresponding author email: yasser_moselhy@yahoo.com

DOI :10.21608/agro.2017.419.1043

C2017 National Information and Documentaion Center (NIDOC)
} 
system (Sujatha et al., 2005 and Datta et al., 2007). As Attaya et al. (2012) reported in vitro techniques are being increasingly applied for clonal propagation of selected tree species to supplement conventional methods which have their limitations especially when a large number of genetically uniform propagules are requiered. Moreover, these technologies would help in producing the active compounds in vitro with better productivities without cutting down the natural resources. Recently, many studies have been reported on Jatropha in vitro propagation through organogenesis from different explants (Datta et al., 2007; Deore \& Johanson, 2008 and Misra et al., 2010) but few are through somatic embryogenesis (Sardana et al., 2000 and Jha et al., 2007). Although shoot multiplication is good but it records low growth quality, show callus formation, low rooting percentage and difficult acclimatization which restricts clonal propagation of quality planting material.

This study aimed to investigate the influence of different plant growth regulators and focusing on the process of adventitious root induction to improve rooting of regenerated shoots, to develop an efficient and reproducible protocol for Jatropha micro propagation that shows no or limited callus induction using shoot tips on different Jatropha curcas lines for mass propagation and genetic improvement.

\section{MATERIALS AND METHODS}

Plant material

Jatropha curcas seeds were collected from Madagascar and Ecuador by Prof. Dr. Patrick Van Damme, Laboratory of Tropical and Subtropical Agronomy and Ethnobotany, Bioscience Engineering Faculty, Ghent University. The seeds were germinated in soil and maintained in laboratory greenhouse. During the period from 2015 to 2016 at in vitro biology and horticulture unit, Plant Science Department, McGill University, Canada, shoot tips of ( $1.5 \mathrm{~cm}$ long) and ( $0.5 \mathrm{~cm}$ wide) from sixmonth-old donor plants were cut. The shoot tips were washed and then submerged in tap water with a drop of liquid soap (DreftTM detergent; Procter and Gamble, Surrey, UK) in a flask and shacked by hand for $5 \mathrm{~min}$ then rinsed in tap water to remove the soap then explants were sterilized with $70 \%$ $(\mathrm{v} / \mathrm{v})$ ethanol for $30 \mathrm{sec}$ and subsequently surface sterilized with $70 \%(\mathrm{v} / \mathrm{v})$ solution of a commercial disinfection product (Haz-taps; Guest Medical, Kent, UK) followed by repeated washing (3 times) with sterile distilled water under aseptic condition in laminar air-flow hood.

\section{Culture media and conditions}

The sterilized explants were trimmed (0.5$1.0 \mathrm{~cm})$ at the base and cultured with the cut surface in contact with MS basal salt mixtures including vitamins medium (Murashige \& Skoog, 1962) supplemented with $30 \mathrm{~g} / \mathrm{l}$ sucrose and included different concentrations of BA, metamethoxytopolin-riboside (Mem-Tr) and Zeatin in addition to $8 \mathrm{~g} / \mathrm{l}$ of agar. $\mathrm{pH}$ of the medium was adjusted to $5.6-5.8$ after gelling with agar and autoclaved at $121^{\circ} \mathrm{C}$ and $1.1 \mathrm{~kg} / \mathrm{cm}^{2}$ for $20 \mathrm{~min}$. The cultures were maintained in an air conditioned incubation room at $25 \pm 2{ }^{\circ} \mathrm{C}$ under 16 $\mathrm{h} /$ day photoperiod which provided by cool white fluorescent lamps (light intensity 2000 Lux.).

\section{In vitro rooting and hardening}

Shoots $(2-4 \mathrm{~cm})$ in length regenerated from in vitro explants were rooted on $1 / 2$ strength $\mathrm{MS}$ medium supplemented with $30 \mathrm{~g} / 1$ sucrose and 8 $\mathrm{g} / \mathrm{l}$ agar with different concentrations of auxins like (IBA - IAA - 2,4-D). To monitor the initiation and quality of adventitious roots on the regenerated shoots, the cultures were maintained by cool white fluorescent lamps as a control treatment provided by Philips, warm white fluorescent lamps provided by Osram (München, Germany) and three Lightemitting-diodes (LEDs) treatments which were blue $(450 \mathrm{~nm})$, red $(660 \mathrm{~nm})$ and white. In the present investigation, healthy in vitro plantlets with well-developed shoots and roots were produced from nodes of two Jatropha curcas lines (Madagascar and Ecuador) through direct adventitious shoot regeneration. Then, well rooted shoots after 6 weeks of culture on root induction medium were carefully taken out of the medium and washed thoroughly in sterilized distilled water to remove medium attached to the roots for $e x$ vitro. The plantlets were then planted into pots containing a mixture of organic soil and sand in the ratio of 1:1 then placed in a plastic tunnel and wetted with tap water followed by covering with transparent plastic bags to maintain humidity. After 3-4 weeks, the established plants were transplanted to poly ethylene bags containing garden soil and farmyard manure for further growth

\section{Statistical analysis}

Statistical difference among the means was analyzed by Duncan's multiple range test (DMRT) at 0.05 level using the SPSS (version 17) and the results were expressed as the mean $\pm \mathrm{SE}$. Data were also subjected to analysis of variance (ANOVA). 


\section{RESULTS AND DISCUSSION}

Shoot multiplication and elongation Effect of PGRs on multiple shoot formation

The experiments conducted to optimize the medium for multiplication of Jatropha curcas lines are summarized in Table 1. The effect of different plant growth regulators on multiple shoot formation was clearly dependent on the used lines. Explants were cultured on full strength MS basal medium including vitamins supplemented with 30 $\mathrm{g} / 1$ sucrose and $8 \mathrm{~g} / \mathrm{l}$ of agar in addition to various cytokinins like (BA, Mem-Tr, Zeatin) individually with different concentrations $(0.1,0.5,1.0 \mathrm{mg} / \mathrm{l})$. The optimum shoot growth with high number was observed using MS medium supplemented with $1.0 \mathrm{mg} / 1 \mathrm{BA}$ in both lines within a period of 3040 days (Table 1; Fig 1) which shows 3.86 and 3.4 shoot buds in Madagascar and Ecuador lines, respectively. followed by the concentration of 1.0 $\mathrm{mg} / \mathrm{l}$ mem-tr that gave the longest shoot length which shows 4.66 and $4.36 \mathrm{~cm}$, respectively but proved to be second best concentration recording 3.66 and 3.13 number of shoots in Madagascar and Ecuador Jatropha, respectively. According to Shrivastava \& Banerjee (2008), there are several reasons for preferred use of BA as cytokinins, slow degradation and it can be autoclaved without losing its activity. On the other hand, by increasing the concentration of BA, mem-tr or zeatin the shoot formation increased in both lines. Moreover, using $1.0 \mathrm{mg} / \mathrm{l}$ zeatin proved to be second best concentration recording 4.33 and $3.63 \mathrm{~cm}$ shoot length in Madagascar and Ecuador lines, respectively.

At the same concentration of $1.0 \mathrm{mg} / \mathrm{l} \mathrm{BA}$ but here in combination with $1.0 \mathrm{mg} / \mathrm{l} \mathrm{IBA}$ (Table 2), a maximum initiation of healthy shoot buds (1.43 and 1.60) were obtained in both lines after 6 weeks of culture. The obtained shoots were lesser in its number than the number in the $1^{\text {st }}$ experiment. However, using $0.5 \mathrm{mg} / 1 \mathrm{BA}$ in the presence of $0.5 \mathrm{mg} / \mathrm{l}$ IBA recorded the second best shoot formation (1.3 and 1.4 shoots /explant) in both lines. The results are in harmony with that found by Datta et al. (2007). In this experiment, the best response of $1.0 \mathrm{mg} / 1 \mathrm{Mem}-\operatorname{Tr}(1.0$ and 1.43 shoots per explant) was obtained in the presence of $1.0 \mathrm{mg} / \mathrm{l}$ IBA which recorded the best shoot length $(1.9$ and $2.1 \mathrm{~cm})$ in both lines, respectively. Moreover, presence of NAA in combination with BA or Mem-Tr did not form any shoots in both Jatropha lines.
Also, addition of IBA along with BA has been reported to regenerate shoot buds from the nodal explants of Jatropha curcas (Shrivastava \& Banerjee, 2008). Moreover, Maharana et al. (2012) mentioned that cytokinins at its high concentration stimulated development of meristems and its optimal concentration promotes shoot proliferations, and the inclusion of low concentration of auxins along with cytokinins triggers the rate of shoot proliferations. This differential response may be attributed to the specific age and physiological condition of the donor plant from which the nodal explants were excised.

Callus formation is a significant problem for Jatropha micropropagation and needs to be minimized. It was observed in the presence of different NAA concentrations. However, adding mem-Tr to the MS medium showed free callus and produced elongated stems and welldeveloped leaves in comparison to BA and Zeatin (data not shown) thus, in the presence of different concentrations of IBA except using it with NAA (Table 2).

\section{In vitro root induction}

\section{Effect of PGRs on root formation}

Adventitious rooting is a complex process and a key step in the vegetative propagation of economically important woody, horticultural and agricultural plant species and is a critical factor for successful production of elite clones (Davis \& Haissig, 1994). In this study, Generated shoots (1-1.5 cm long) were cultured on half MS basal salt without vitamins medium containing IBA concentrations $(0.0-0.1-0.5-1.0-2.5-$ 12.5) $\mathrm{mg} / \mathrm{l}$ with five folds rate. IBA significantly increased the root formation percentage and the number of roots per shoot compared to the control. The optimum rooting medium with good root formation (46.6 and 40\%) in both Jatropha lines and $(3.03-2.43)$ roots per shoot containing half-strength MS supplemented with $0.5 \mathrm{mg} / 1 \mathrm{IBA}$ (Table 3). However, a higher concentration of IBA $(12.5 \mathrm{mg} / \mathrm{l})$ in MS medium inhibited the root formation and formed small callus growth less than $5 \mathrm{~mm}$ diameter at the basal end of shoots. similar findings have also been reported by Bhatt \& Tomar (2010) and Toppo et al. (2012) that indicate low IBA concentration $(0.5 \mathrm{mg} / \mathrm{l})$ were found to be more effective for root primordia initiation. Rajore \& Batra (2005) cleared that IBA from 0.5 to $5 \mathrm{mg} / \mathrm{l}$ incorporated singly in MS found suitable for root induction. In other papers, 
TABLE1. Influence of plant growth regulator (PGRs) on multiple shoot formation from nodal explants of different Jatropha curcas lines.

\begin{tabular}{|l|c|c|c|c|c|c|c|}
\hline $\begin{array}{l}\text { Plant growth } \\
\text { regulator }\end{array}$ & $\begin{array}{l}\text { Amount of } \\
\text { PGR (mg/l) }\end{array}$ & \multicolumn{2}{|c|}{$\begin{array}{c}\text { Shoot formation } \\
(\mathbf{\%})\end{array}$} & \multicolumn{2}{c|}{ No. of shoots/explant } & \multicolumn{2}{c|}{$\begin{array}{c}\text { Average shoot length } \\
\text { (cm) }\end{array}$} \\
\cline { 2 - 8 } & & Mad. & Ecu. & Mad. & Ecu. & Mad. & Ecu. \\
\hline \multirow{4}{*}{ BA } & $\mathbf{0 . 0}$ & 43.3 & 50.0 & $0^{\mathrm{g}}$ & $0^{\mathrm{g}}$ & $1.26 \pm 0.14^{\mathrm{f}}$ & $0.73 \pm 0.12^{\mathrm{h}}$ \\
\cline { 2 - 8 } & $\mathbf{0 . 1}$ & 73.3 & 76.6 & $2.96 \pm 0.08^{\mathrm{c}}$ & $2.66 \pm 0.12^{\mathrm{c}}$ & $1.7 \pm 0.11^{\mathrm{e}}$ & $1.3 \pm 0.05^{\mathrm{g}}$ \\
\cline { 2 - 8 } & $\mathbf{0 . 5}$ & 96.6 & 93.3 & $3.46 \pm 0.14^{\mathrm{b}}$ & $3.03 \pm 0.08^{\mathrm{b}}$ & $2.66 \pm 0.08^{\mathrm{c}}$ & $2.2 \pm 0.10^{\mathrm{e}}$ \\
\cline { 2 - 8 } & $\mathbf{1 . 0}$ & 100 & 100 & $3.86 \pm 0.14^{\mathrm{a}}$ & $3.4 \pm 0.11^{\mathrm{a}}$ & $3.4 \pm 0.11^{\mathrm{b}}$ & $3.16 \pm 0.12^{\mathrm{c}}$ \\
\hline Mem-Tr & $\mathbf{0 . 1}$ & 66.6 & 73.3 & $1.23 \pm 0.14^{\mathrm{f}}$ & $0.9 \pm 0.15^{\mathrm{f}}$ & $2.26 \pm 0.14^{\mathrm{d}}$ & $1.7 \pm 0.15^{\mathrm{f}}$ \\
\cline { 2 - 8 } & $\mathbf{0 . 5}$ & 93.3 & 96.6 & $2.33 \pm 0.17^{\mathrm{d}}$ & $1.93 \pm 0.08^{\mathrm{d}}$ & $3.2 \pm 0.11^{\mathrm{b}}$ & $2.6 \pm 0.15^{\mathrm{d}}$ \\
\cline { 2 - 8 } & $\mathbf{1 . 0}$ & 96.6 & 100 & $3.66 \pm 0.08^{\mathrm{ab}}$ & $3.13 \pm 0.08^{\mathrm{ab}}$ & $4.66 \pm 0.08^{\mathrm{a}}$ & $4.36 \pm 0.03^{\mathrm{a}}$ \\
\hline Zeatin & $\mathbf{0 . 1}$ & 40.0 & 53.3 & $1.26 \pm 0.08^{\mathrm{f}}$ & $1.06 \pm 0.12^{\mathrm{ef}}$ & $2.26 \pm 0.08^{\mathrm{d}}$ & $1.73 \pm 0.12^{\mathrm{f}}$ \\
\cline { 2 - 8 } & $\mathbf{0 . 5}$ & 43.3 & 56.6 & $1.83 \pm 0.12^{\mathrm{e}}$ & $1.26 \pm 0.12^{\mathrm{e}}$ & $3.16 \pm 0.12^{\mathrm{b}}$ & $2.56 \pm 0.13^{\mathrm{d}}$ \\
\cline { 2 - 8 } & $\mathbf{1 . 0}$ & 66.6 & 70.0 & $1.46 \pm 0.08^{\mathrm{f}}$ & $1.1 \pm 0.05^{\mathrm{ef}}$ & $4.33 \pm 0.08^{\mathrm{a}}$ & $3.63 \pm 0.16^{\mathrm{b}}$ \\
\hline
\end{tabular}

Means \pm SE (standard error) in each column followed by same letters are not significantly different according to .Dunchan's multiple range test (DMRT) at $\alpha=0.05$

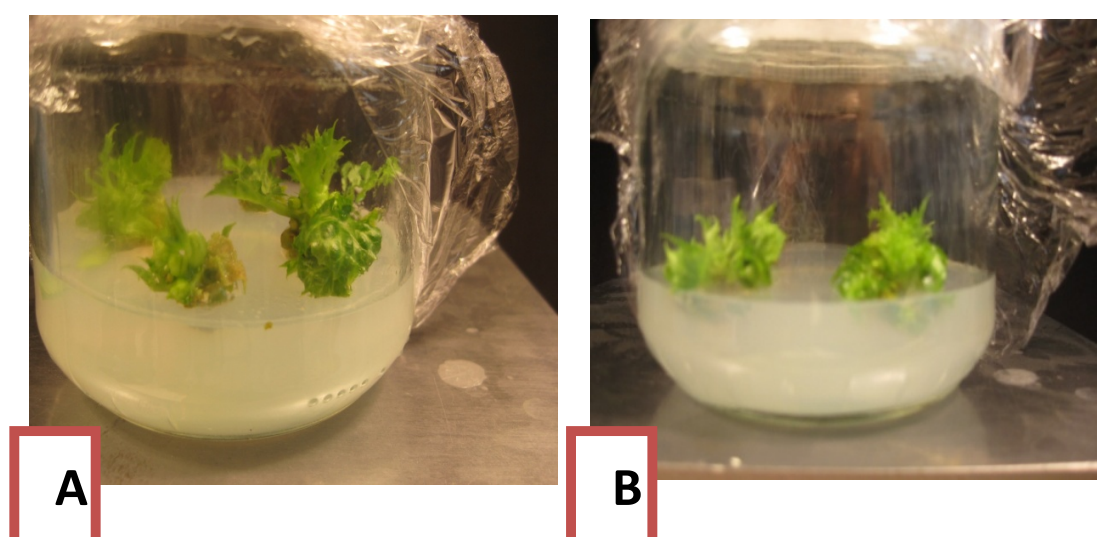

Fig.1. Shoot multiplication on Jatropha curcas explants using 1.0 mg/l BA: A, Madagascar line; B, Ecuador line

TABLE 2 . Effect of different concentrations and combination of PGRs on multiple shoot formation of different jatropha curcas lines.

\begin{tabular}{|c|c|c|c|c|c|c|c|c|c|}
\hline \multirow{2}{*}{\multicolumn{4}{|c|}{ Plant growth regulators $(\mathrm{mg} / \mathrm{l})$}} & \multicolumn{2}{|c|}{ No. of shoots/explant } & \multicolumn{2}{|c|}{ Shoot length $(\mathrm{cm})$} & \multicolumn{2}{|c|}{$\begin{array}{l}\text { Degree of callus } \\
\text { formation }\end{array}$} \\
\hline & & & & Mad. & Ecu. & Mad. & Ecu. & Mad. & Ecu. \\
\hline BA & $\begin{array}{c}\text { Mem- } \\
\text { TR }\end{array}$ & IBA & NAA & & & & & & \\
\hline 0.1 & - & 0.1 & - & $1.0 \pm 0.00^{\mathrm{c}}$ & $1.26 \pm 0.08^{\mathrm{b}}$ & $0.7 \pm 0.05^{\mathrm{d}}$ & $0.83 \pm 0.03^{\mathrm{d}}$ & - & - \\
\hline 0.5 & - & 0.5 & - & $1.3 \pm 0.11^{b}$ & $1.4 \pm 0.05^{\mathrm{b}}$ & $1.03 \pm 0.03^{\mathrm{c}}$ & $1.5 \pm 0.05^{b}$ & + & + \\
\hline 1.0 & - & 1.0 & - & $1.43 \pm 0.06^{\mathrm{a}}$ & $1.6 \pm 0.11^{\mathrm{a}}$ & $0.73 \pm 0.06^{\mathrm{d}}$ & $1.03 \pm 0.06^{\mathrm{c}}$ & + & + \\
\hline 0.1 & - & - & 0.1 & $0^{\mathrm{e}}$ & $0^{\mathrm{e}}$ & $0^{\mathrm{e}}$ & $0^{\mathrm{f}}$ & + & + \\
\hline 0.5 & - & - & 0.5 & $0^{\mathrm{e}}$ & $0^{\mathrm{e}}$ & $0^{\mathrm{e}}$ & $\frac{0^{f}}{4}$ & ++ & ++ \\
\hline 1.0 & - & - & 1.0 & $0^{\mathrm{e}}$ & $0^{\mathrm{e}}$ & $0^{\mathrm{e}}$ & $0^{f}$ & +++ & +++ \\
\hline- & 0.1 & $\overline{0.1}$ & - & $0^{\mathrm{e}}$ & $0.63 \pm 0.06^{\mathrm{d}}$ & $0^{\mathrm{e}}$ & $0.53 \pm 0.03^{\mathrm{e}}$ & - & - \\
\hline- & 0.5 & 0.5 & - & $0.8 \pm 0.05^{\mathrm{d}}$ & $1.06 \pm 0.06^{\mathrm{c}}$ & $1.23 \pm 0.12^{b}$ & $1.56 \pm 0.03^{b}$ & - & - \\
\hline- & 1.0 & 1.0 & - & $1.1 \pm 0.05^{\mathrm{c}}$ & $1.43 \pm 0.08^{\mathrm{ab}}$ & $1.96 \pm 0.12^{\mathrm{a}}$ & $2.13 \pm 0.08^{\mathrm{a}}$ & - & - \\
\hline- & 0.1 & - & 0.1 & $0^{\mathrm{e}}$ & $0^{\mathrm{e}}$ & $0^{\mathrm{e}}$ & $0^{\mathrm{f}}$ & + & + \\
\hline- & 0.5 & - & 0.5 & $0^{\mathrm{e}}$ & $0^{\mathrm{e}}$ & $0^{\mathrm{e}}$ & $0^{\mathrm{f}}$ & + & + \\
\hline- & 1.0 & - & 1.0 & $0^{\mathrm{e}}$ & $0^{\mathrm{e}}$ & $0^{\mathrm{e}}$ & $0^{f}$ & + & + \\
\hline
\end{tabular}

Data $($ Mean $\pm \mathrm{SE}$ ) recorded after 6 weeks. callus formation (-, no callus ; +, small callus less than 5 mm diameter ; .++ , moderate callus 5-10 $\mathrm{mm}$ diameter ; +++, large callus more than $10 \mathrm{~mm}$ diameter 
TABLE 3 . Influence of different concentrations of IBA on adventitious root formation of different Jatropha

\begin{tabular}{|c|c|c|c|c|c|c|c|c|}
\hline \multirow{3}{*}{$\begin{array}{l}\text { IBA } \\
\text { concentration } \\
\text { (mg) }\end{array}$} & \multicolumn{8}{|c|}{ Average growth } \\
\hline & \multicolumn{2}{|c|}{ Root formation (\%) } & \multicolumn{2}{|c|}{ No. of roots/explant } & \multicolumn{2}{|c|}{ Root length $(\mathrm{cm})$} & \multicolumn{2}{|c|}{ Callus formation } \\
\hline & Mad. & Ecu. & Mad. & Ecu. & Mad. & Ecu. & Mad. & Ecu. \\
\hline 0 & 0 & 0 & $0^{\mathrm{d}}$ & $0^{d}$ & $0^{d}$ & $0^{d}$ & - & - \\
\hline 0.1 & 36.6 & 33.3 & $2.16 \pm 0.08^{b}$ & $1.76 \pm 0.08^{b}$ & $1.8 \pm 0.05^{\mathrm{b}}$ & $1.33 \pm 0.12^{b}$ & - & - \\
\hline 0.5 & 46.6 & 40.0 & $3.03 \pm 0.12^{\mathrm{a}}$ & $2.43 \pm 0.21^{\mathrm{a}}$ & $2.7 \pm 0.25^{a}$ & $2.13 \pm 0.08^{\mathrm{a}}$ & - & - \\
\hline 2.5 & 13.3 & 23.3 & $1.1 \pm 0.11^{\mathrm{c}}$ & $0.66 \pm 0.08^{c}$ & $0.7 \pm 0.11^{c}$ & $0.7 \pm 0.05^{c}$ & - & - \\
\hline 12.5 & 0 & 0 & $0^{d}$ & $0^{d}$ & $0^{d}$ & $0^{d}$ & + & + \\
\hline
\end{tabular}

Means \pm SE (standard error) in each column followed by same letters are not significantly different according to .Duncan's multiple range test (DMRT) at $\alpha=0.05$

IBA was reported as most effective auxin for in vitro rhizogenesis in Jatropha curcas. Also, these results are in agreement with those of Datta et al. (2007), Rajore \& Batra (2007), Shrivastava \& Banerjee (2008) and Kaewpoo \& Te-chato (2009). In contrast, Kalimuthu et al. (2007) and Sujatha \& Mukta (1996) found in their studies that IAA was found to be more suitable hormone than IBA for root induction.

In this investigation, $0.5 \mathrm{mg} / 1 \mathrm{IBA}$ individual and in combination with three concentrations of IAA and 2,4-D $(0.1-0.5-1.0 \mathrm{mg} / \mathrm{l})$ were used to study its effect on adventitious root formation. The maximum number of roots (3.1 and 2.7) were observed in half strength MS basal salts supplemented with $0.5 \mathrm{mg} / \mathrm{l}$ with longest root length $(2.7$ and $2.1 \mathrm{~cm})$ (Table 4). However, increasing the concentration of IBA from 0.5 to $2.0 \mathrm{mg} / \mathrm{l}$ decreased root formation and number of roots per shoot of different Jatropha lines. Also, it was found that addition of auxins like IAA or 2,4-D with different concentrations to the basal MS medium including $0.5 \mathrm{mg} / 1 \mathrm{IBA}$ inhibited the root formation and observed small to large callus growth. The induction of excessive callus formation was avoided only on IBA containing medium individually but in the presence of IAA and 2,4-D, excessive callus growth was formed at the basal end of shoots.

Influence of LED plant light technology on root formation

In the present study, different light sources like cool white fluorescent (CWF), warm white fluorescent (WWF) and different high- brightness LEDs (red - blue - white) were used to monitor the root initiation of in vitro Jatropha shoots. Red light provided the most favorable growth conditions inducing a rooting response in $66.6 \%$ of the shoots in Madagascar Jatropha and 56.5\% in Ecuador Jatropha (Table 5 and Fig. 2) which produced on average 4.2 and 3.5 roots per shoot, respectively in both lines. Followed by incubation under LED blue light that recorded the second best number of roots (3.5 and 2.9) in both lines, respectively. Then, cool white fluorescent lambs that produced 3.0 roots per shoot in Madagascar line and 2.5 roots per shoot in Ecuador line, these findings are the same according to Shin et al. (2008) and Nhut \& Nam (2010) who found that root growth was optimum and higher in plants grown under blue light than that under PGF. Furtherore, white LED light was more effective on root elongation than all studied light treatments that recorded $(5.6$ and $4.4 \mathrm{~cm})$ root length in both lines, followed by LED blue light which resulted $(3.8$ and $3.1 \mathrm{~cm})$ root length. On the other side, shoots incubated under warm white fluorescent lambs did not form any root initiation.

The results are in agreement with Daud et al. (2013) who mentioned that Jatropha curcas plantlets regenerated from shoots incubated under constant red light performed slightly better than plantlets regenerated from shoots incubated under fluorescent light because the led red light increases the percentage of root formation, number of roots and root length of Jatropha curcas with limited or no necrosis. Also, the results in agreement with Nhut et al. (2003) who cultured strawberry plantlets under different blue to red LED ratios as well as irradiation levels and compare its growth, they noticed that the number of roots and root length of strawberry under red LEDs was higher than that of blue LEDs. On the contrary, the data disagree with those observed by (Iacona and Muleo 2010) who found that blue light was more effective for the induction of adventitious rooting of cherry rootstock. 
TBLE 4 . Effects of different concentrations and combination of auxins on adventitious root formation from in vitro grown shoots cultured on $1 / 2$ MS medium.

\begin{tabular}{|c|c|c|c|c|c|c|c|}
\hline \multirow{2}{*}{$\begin{array}{l}\text { Plant growth } \\
\text { regulators }\end{array}$} & \multirow{2}{*}{$\begin{array}{l}\text { Amount of } \\
\text { PGR (mg/l) }\end{array}$} & \multicolumn{2}{|c|}{ No. of roots/shoot } & \multicolumn{2}{|c|}{ Average root length $(\mathrm{cm})$} & \multicolumn{2}{|c|}{ Degree of callus formation } \\
\hline & & Mad. & Ecu. & Mad. & Ecu. & Mad. & Ecu. \\
\hline \multirow{4}{*}{ IBA } & 0 & $0^{e}$ & $0^{d}$ & $0^{\mathrm{d}}$ & $0^{e}$ & - & - \\
\hline & 0.5 & $3.1 \pm 0.11^{\mathrm{a}}$ & $2.7 \pm 0.05^{\mathrm{a}}$ & $2.73 \pm 0.12^{\mathrm{a}}$ & $2.13 \pm 0.08^{\mathrm{a}}$ & - & - \\
\hline & 1.0 & $2.1 \pm 0.05^{b}$ & $1.73 \pm 0.17^{b}$ & $1.43 \pm 0.06^{b}$ & $1 \pm 0.03^{b}$ & - & - \\
\hline & 2.0 & $1.26 \pm 0.08^{\mathrm{c}}$ & $0.93 \pm 0.06^{c}$ & $0.8 \pm 0.05^{c}$ & $0.63 \pm 0.03^{\mathrm{d}}$ & - & - \\
\hline \multirow{3}{*}{ IBA $0.5+$ IAA } & 0.1 & $1 \pm 0.00^{\mathrm{d}}$ & $0.76 \pm 0.03^{c}$ & $1.23 \pm 0.08^{b}$ & $0.76 \pm 0.03^{c}$ & + & + \\
\hline & 0.5 & $1 \pm 0.00^{\mathrm{d}}$ & $0.73 \pm 0.03^{c}$ & $0.66 \pm 0.12^{c}$ & $0.56 \pm 0.03^{\mathrm{d}}$ & + & ++ \\
\hline & 1.0 & $0^{e}$ & $0^{\mathrm{d}}$ & $0^{\mathrm{d}}$ & $0^{\mathrm{e}}$ & +++ & +++ \\
\hline \multirow{3}{*}{ IBA $0.5+2,4-\mathrm{D}$} & 0.1 & $1 \pm 0.00^{\mathrm{d}}$ & $0.83 \pm 0.08^{\mathrm{c}}$ & $0.76 \pm 0.08^{c}$ & $0.63 \pm 0.03^{\mathrm{d}}$ & + & + \\
\hline & 0.5 & $0^{\mathrm{e}}$ & $0^{\mathrm{d}}$ & $0^{\mathrm{d}}$ & $0^{\mathrm{e}}$ & + & + \\
\hline & 1.0 & $0^{e}$ & $0^{d}$ & $0^{\mathrm{d}}$ & $0^{\mathrm{e}}$ & ++ & +++ \\
\hline
\end{tabular}

Data (Means \pm SE) in each column followed by same letters are not significantly different according to Dunchan's .multiple range test (DMRT) at $\alpha=0.05$

TABLE 5. Influence of different light treatments on Jatropha curcas root formation.

\begin{tabular}{|l|c|c|c|c|c|c|}
\hline \multirow{2}{*}{ Light treatment } & \multicolumn{2}{|c|}{ Root formation (\%) } & \multicolumn{2}{c|}{ No. of roots/explant } & \multicolumn{2}{c|}{ Root length (cm) } \\
\cline { 2 - 7 } & Mad. & Ecu. & Mad. & Ecu. & Mad. & Ecu. \\
\hline Cool light fluorescent & 53.3 & 56.6 & $3 \pm 0.05^{\mathrm{c}}$ & $2.56 \pm 0.12^{\mathrm{c}}$ & $2.53 \pm 0.14^{\mathrm{d}}$ & $1.93 \pm 0.08^{\mathrm{c}}$ \\
\hline Warm light fluorescent & 0 & 0 & $0^{\mathrm{e}}$ & $0^{\mathrm{e}}$ & $0^{\mathrm{e}}$ & 0 \\
\hline LED red & 66.6 & 56.6 & $4.23 \pm 0.14^{\mathrm{a}}$ & $3.5 \pm 0.05^{\mathrm{a}}$ & $3.2 \pm 0.11^{\mathrm{c}}$ & $2.8 \pm 0.15^{\mathrm{b}}$ \\
\hline LED blue & 43.3 & 46.6 & $3.5 \pm 0.15^{\mathrm{b}}$ & $2.93 \pm 0.08^{\mathrm{b}}$ & $3.83 \pm 0.14^{\mathrm{b}}$ & $3.16 \pm 0.03^{\mathrm{b}}$ \\
\hline LED white & 26.6 & 33.0 & $1.36 \pm 0.12^{\mathrm{d}}$ & $1 \pm 0.00^{\mathrm{d}}$ & $5.6 \pm 0.11^{\mathrm{a}}$ & $4.43 \pm 0.21^{\mathrm{a}}$ \\
\hline
\end{tabular}

Data collected after 45 days, 30 explants per condition were used, Means \pm SE (standard error) in each column followed by same letters are not significantly different according to Duncan's multiple range test (DMRT) at $\alpha=$ .0 .05

\section{Acclimatization and field transfer}

Well-developed healthy in vitro rooted plantlets after 6 weeks were washed thoroughly in running tap water and hardened for ex vitro. The plantlets were planted into pots containing a mixture of organic soil and sand in the ratio of $1: 1$ then placed in a plastic tunnel and wetted with tap water followed by covering with transparent plastic bags to maintain humidity. After 3-4 weeks, the established plants were transplanted to poly ethylene bags containing garden soil and farmyard manure for further growth. The survival rate of in vitro propagated plantlets after transplanting was $40-60 \%$ and they grew as normal plants.

\section{CONCLUSIONS}

An efficient and reproducible protocol was developed for plant regeneration of elite genotypes (Madagascar and Ecuador) of Jatropha curcas plants. A reliable micropropagation method of Jatropha plants from nodal explants with much higher rate of multiplication was described . Using new LED light technology, is a promising method for elite propagation, especially red for roots number and blue for root length.

\section{ACKNOWLEDGMENTS}

Deep gratitude to Prof. Dr. ir. Patrick Van Damme, Laboratory of Tropical, Subtropical Agronomy \& Ethnobotany for using Jatropha plant material from laboratory greenhouse. Also, my gratitude is further extended to employees of In vitro culture and horticulture Unit, for encouragement and for all facilities supported during the present study. 

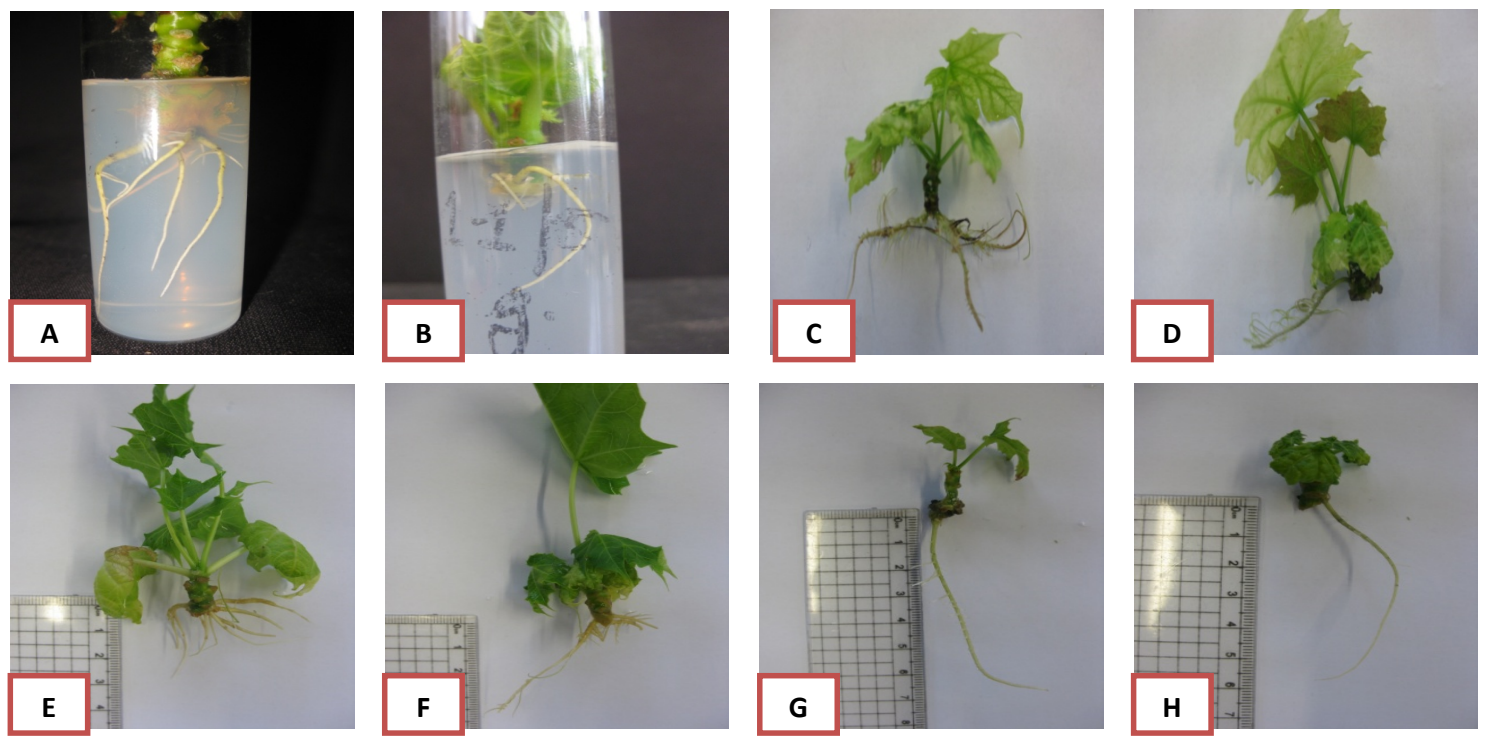

Fig 2. Adventitious rooting of Madagascar and Ecuador $J$. curcas lines respectively using $0.5 \mathrm{mg} / \mathrm{I}$ IBA under different light treatments: A,B, cool white fluorescent; C,D, LED red light; E,F, LED blue light; G,H, LED white light

\section{REFERENCES}

Abdulla, R., Chan, E.S. and Ravindra, P (2011) Biodiesel production from Jatropha curcas: a critical review. Crit Rev in Biotech.31,53-64.

Achten, W.M.J., Mathijs,E., Verchot, L., Singh, V.P., Aerts, R. and Muys, B. (2007) Jatropha biodiesel fueling sustainability. Biof. Bioprod Biorefin 1, 283-291.

Attaya, A.S., Geelen, D. and Belal, A.H. (2012) Progress in Jatropha curcas tissue culture. Am. Eur . J. Sus.Agr. 6 1, 6- 13.

Bhatt, B. and Tomar, Y. (2010) Effects of IBA on rooting performance of Citrus auriantifolia Swingle (Kagzilime) in different growing conditions. Nat. Sci. 8, 8-11.

Daud, N., Faizal, A. and Geelen, D. (2013) Adventitious rooting of Jatropha curcas L. is stimulated by phloroglucinol and by red LED light. In vitro Cell Dev. Biol. Plant, 49,183-190.

Datta, M.M., Mukherjee, P., Ghosh, B. and Jha, T.B. (2007) In vitro clonal propagation of biodiesel plant (J. curcas L.). Curr. Sci. 93, 1438-1442.

Davis, T. and Haissig, B. (1994) "Biology of Adventitious Root Formation." Plenum Press, New York

Deore. A.C. and Johnson, T.S. (2008) Highfrequency plant regeneration from leaf-disc cultures of J. curcas L.: an important biodiesel plant. Plant Biotech Rep. 2,7-11.

Francis, G., Edinger, R. and Becker, K. (2005) A concept for simultaneous wasteland reclamation, fuel production and socioeconomic development in degraded areas in India: need, potential and persepectives of Jatropha plantations. Nat Resou Forum, 29,12-24.

Iacona, C. and Muleo, R. (2010) Light quality affects in vitro adventitious rooting and ex vito performance of cherry rootstock Colt. Sci Hortic. 125, 630-636.

Jha, T.B., Mukherjee, P. and Datta, M.M. (2007) Somatic embryogenesis in J. curcas L., an important biofuel plant. Plant Biotech. Rep. 1,135-140.

Jones, N. and Miller, J.H. (1991) Jatropha curcas: a multipurpose species for problematic sites. Land Resource Series, 1,1-12.

Kaewpoo, M. and Te-chato, S (2009) Influence of explants types and plant growth regulators on multiple shoot formation from Jatropha curcas. Scie Asia, 35,353-357.

Kalimuthu, K., Paulsamy, S. and Senthilkumar, Sathya, M. (2007) In vitro propagation of Biodiesel plant J. curcas L. Plant Tiss Cult Biotech 2,137-147.

Kumar, A. and Sharma, S. (2008) An evaluation of multipurpose oil seed crop for industrial uses (Jatropha curcas L.): a review. Ind. Crops Prod. 28,1-10.

Li, M., Li, H., Jiang, H., Pan, X. and Wu, G. (2007) Establishment of an Agrobacteriuim-mediated cotyledon disc transformation method for Jatropha curcas. Plant Cell Tiss Org Cult 92,173-181.

Maharana, S.B., Mahato, V., Behera, M., Mishra, R.R. and Panigrahi, J. (2012) In vito regeneration from node and leaf explants of Jatropha curcas L. and evaluation of genetic fidelity through RAPD markers. Indian Journal of Biot. 11,280-287.

Menezes, R.G., Rao, N.G., Karanth, S.S., Kamath 
A., Manipady, S. and Pillay, V.V. (2006) J. curcas poisoning. Ind $J$ Pediatr 73,634.

Misra, P., Gupta, N., Toppo, D.D., Pandy, V., Mishra, M.K. and Tuli, R. (2010) Establishment of long-term proliferating shoot cultures of elite Jatropha curcas L. by controlling endophytic bacterial contamination. Plant Cell Tiss. Org. 100 (2), 189-197.

Murashige, T. and Skoog, F. (1962) A revised medium for rapid growth and bioassay with tobacco tissue cultures. Physio Planta, 15,473-479.

Nhut, D.T. and Nam, N.B. (2010) Light-emitting diodes (LEDs): an artificial lighting source for biological studies. In the Proceedings of the $3^{\text {rd }}$ International Conference on the Development of BME in Vietnam, pp.133-138.

Nhut, D.T., Takamura, T., Watanabe, H., Okamoto, K. and Tanaka, M. (2003) Response of strawberry plantlets cultured in vitro under superbright red and blue light-emitting diodes (LEDs). Plant Cell Tissue Organ Culture, 73,43-52.

Rajore,S. and Batra, A. (2005) Efficient plant regeneration via shoot tip explants in Jatropha curcas. J Plant. Bioch Biotech 14,73-75.

Rajore, S. and Batra, A. (2007) An alternative source for regenerable organogenic callus induction in Jatropha curcas. Ind J Biotech. 6,545-548.
Sardana, J., Batra, A. and Ali, D.J. (2000) An expeditious method for regeneration of somatic embryos in Jatropha curcas L. Phytomorphology Journal, 50(3-4),239-242.

Shin, K.S., Murthy, H.N., Heo, J.W., Hahn, E.J. and Paek, K.Y. (2008) The effect of light quality on the growth and development of in vitro cultured Dorita enopsis plants. Acta Physiol Plant, 30,339343.

Shrivastava, S. and Banerjee, M.(2008) In vitro clonal propagation of physic nut (J. curcas L.): Influence of additives. Inter J Integr Biol.3,73-79.

Sujatha, M., Makkar, H.P.S. and Becker, K . (2005) Shoot bud proliferation from axillary nodes and leaf sections of non-toxic $J$. curcas L.Plant Grow Regu. 47,83-90.

Sujattha, M. and Mukta, N. (1996) Morphogenesis and plant regeneration from tissue cultures of Jatropha curcas.Plant Cell Tiss Org Cult. 44,135141.

Swarup, R. (2004) Biotechnological interventions to improve Jatropha seeds and oil quality. SAARC Oil \& Fats Today, 39-41.

Toppo, D.D., Singh, G., Purshottam, D.K. and Misra, P (2012) Improved in vitro rooting and acclimatization of Jatropha curcas plantlets. Biomass And Bioenergy Journal, 44,42-46.

\title{
تنظيم التكشف العضوي باستخدام منظمات النمو النباتية وتكنولوجيا الإضاءة الحديثة (الليا) \\ لنباتات الجحاتروفا
}

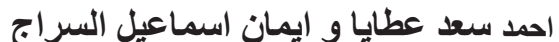 \\ قسم الإنتاج النباتي - كلية العلوم الزر اعية البيئية - جامعة العريش - شمال سيناء ـ مصر
}

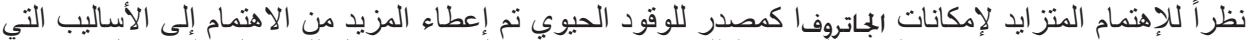

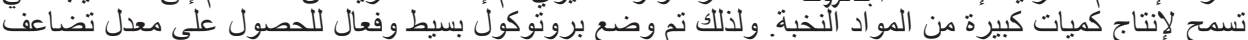

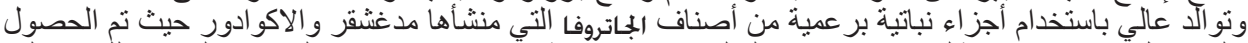

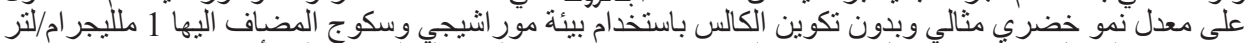

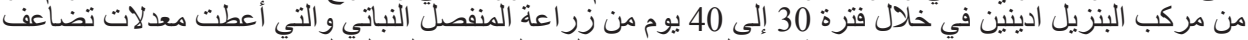

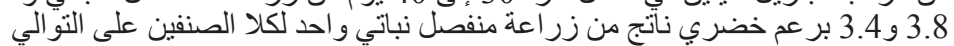

كذللك فان الأجز اء الخضرية الصحية التي تمت استطالتها تم زر اعتها على نصف فئل قوة بيئة مور اشيجي وسكوج

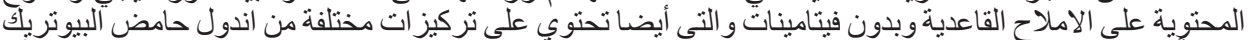

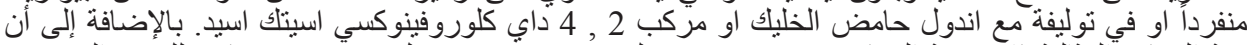

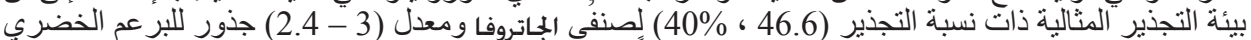

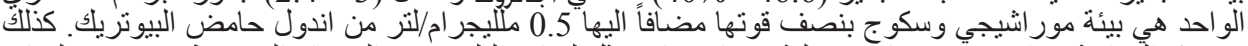

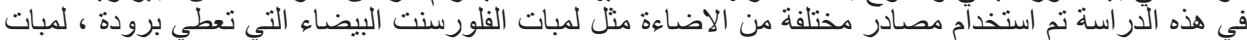

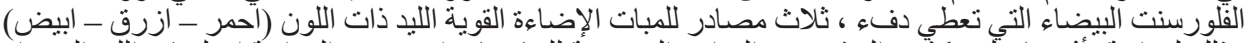

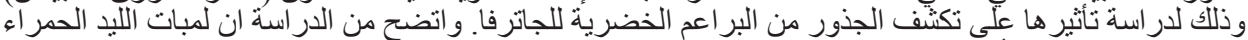

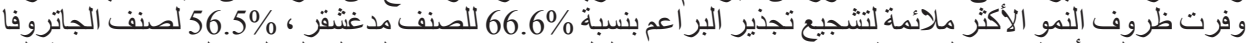

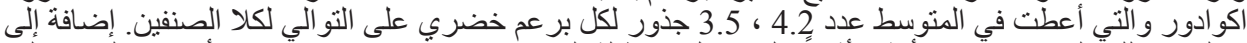

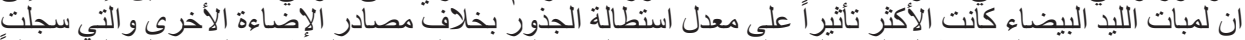

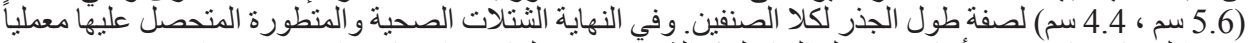

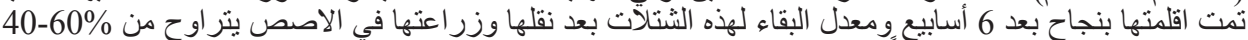

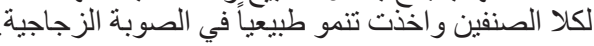

